\title{
Formation of transparent exopolymeric particles (TEP) from macroalgal detritus
}

\author{
Daniel C. O. Thornton* \\ Integrative Biology Group, Darwin Building, School of Health, Natural and Social Sciences, University of Sunderland, \\ Sunderland SR1 3SD, UK \\ Present address: Department of Oceanography, Texas A\& M University, 3146 TAMU, College Station, \\ Texas 77843-3146, USA
}

\begin{abstract}
Detritus derived from macroalgae often accumulates in the littoral and sublittoral of temperate shores. Experiments were conducted to test the hypothesis that macroalgal detritus is a source of transparent exopolymer particles (TEP). Macroalgal detritus was incubated in artificial seawater media under various experimental conditions. TEP concentrations were found to be proportional to the concentration of macroalgal detritus; however, dissolved carbohydrate concentrations were not related to detritus concentration. As TEP concentration did not increase over time, it was probably washed off the detritus when it was initially placed in the media. However, higher concentrations of TEP (262 $\mu \mathrm{g}$ Gum Xanthan equivalent [g detritus] ${ }^{-1}$ ) were produced if inorganic nutrients were added to the media compared to controls (75 $\mu \mathrm{g}$ Gum Xanthan equivalent $\left[\mathrm{g}\right.$ detritus] $\left.{ }^{-1}\right)$. Dissolved carbohydrate and TEP concentrations increased with incubation temperature. TEP did not form abiotically from carbohydrate precursors derived from macroalgal detritus, indicating that microbial activity was important in their formation. TEP from macroalgal detritus will result in a flux of small, sticky particles into the water column which may subsequently affect the aggregation of both biotic and abiotic particles. This will affect both biogeochemical nutrient cycling in coastal waters and food web dynamics.
\end{abstract}

KEY WORDS: Transparent exopolymer particles - TEP · Macroalgae - Detritus - Carbohydrate . Biogeochemistry · Coastal waters

\section{INTRODUCTION}

Transparent exopolymer particles (TEP) are ubiquitous and abundant particles in the ocean which have an important role in the structuring of food webs and the biogeochemical cycling of elements (Passow 2002a). TEP were first described by Alldredge et al. (1993) in Californian coastal waters, occurring in concentrations of 28 to 5000 particles $\mathrm{ml}^{-1}$ with lengths of 3 to $100 \mu \mathrm{m}$. TEP had not been noticed by previous research due to their transparency under the light microscope. Alldredge et al. (1993) made these particles visible by polysaccharide-specific staining techniques with the cationic dye Alcian blue.

TEP are important in the flux of organic matter and energy through the ocean for 2 reasons. Firstly, TEP have been shown to be sticky and involved in the aggregation of particles into larger particles, called marine snow, therefore affecting the sinking rate of organic matter through the water column and to the seafloor (Passow et al. 2001, Passow 2002a). Secondly, the presence of exopolymers as discrete particles rather than dissolved molecules has several biogeochemical implications (Passow \& Alldredge 1995, Passow 2002a). For example, TEP may be available to protozoan and metazoan grazers, unlike the dissolved polysaccharides which are the precursors of TEP (Passow 2002a). TEP provide surfaces for colonisation by organisms and a significant proportion (0.5 to $20 \%$ ) of bacteria in the water column may be associated with TEP (Mari \& Kiørboe 1996). Marine snow aggregates are hotspots of bacterial growth, decomposition of organic matter and nutrient regeneration in the water column (Azam \& Long 2001, Simon et al. 2002). Many 
of these issues were recently reviewed by Passow (2002a).

Since the initial observations of Alldredge et al. (1993), work on TEP has focused on their production by phytoplankton and bacterioplankton (Stoderegger \& Herndl 1999, Passow 2002a,b). TEP abundance is usually positively correlated with phytoplankton biomass (Passow 2002a, Simon et al. 2002). Diatoms are particularly important producers of TEP (Thornton 2002), as demonstrated through laboratory experiments (Alldredge et al. 1993, Crocker \& Passow 1995, Mari 1999, Corzo et al. 2000) and field observation (Passow et al. 1994, Engel 2000, Ramaiah et al. 2001). However, phytoplankton and bacterioplankton may not be the only significant sources of TEP and its polysaccharide precursors. Ramaiah et al. (2001) found that a commercially cultivated macroalga (Undaria pinnatifida) was a significant source of TEP in Japanese coastal waters. TEP production from macroalgae and macroalgal detritus may affect particle dynamics in coastal waters and represent a significant pathway transferring carbon originally fixed by macroalgae to planktonic and benthic communities further offshore.

The aim of this work was to investigate whether the accumulations of macroalgal detritus found in the intertidal zone of a temperate beach (see Fig. 1) were a significant source of TEP. Five hypotheses were tested: (1) macroalgal detritus is a source of TEP; (2) temperature, (3) inorganic nutrient concentrations and (4) microbial activity affect TEP production from macroalgal detritus; (5) TEP forms abiotically from dissolved carbohydrates produced during the decomposition of macroalgal detritus.

\section{MATERIALS AND METHODS}

Collection of material from the field. Macroalgal detritus and seawater were collected at low tide from the shore at Whitburn on the NE coast of England (National grid reference NZ $414616 ; 54^{\circ} 57^{\prime} \mathrm{N}, 1^{\circ} 21^{\prime} \mathrm{W}$ ). Macroalgal detritus was collected from accumulations on the surface of the beach (see Fig. 1). The material used in the experiments was composed of small macroalgal fragments such as those in Fig. 1c. The detritus was placed in a polyethylene bag and it was kept moist by the addition of a little site seawater. Seawater was collected in a 201 polyethylene container and the temperature was measured using an alcohol thermometer. On return to the laboratory, the seawater was filtered through a GF/C (Whatman) followed by a $0.2 \mu \mathrm{m}$ polycarbonate filter (Cyclopore, Whatman). Macroalgal detritus and seawater were stored in a cold room at $5^{\circ} \mathrm{C}$ and were used for experiments within $10 \mathrm{~d}$; most experiments were conducted within $3 \mathrm{~d}$ of collection.
Dry weight of detritus. Ten replicates of approximately $3 \mathrm{~g}$ of detritus were weighed into $5 \mathrm{ml}$ glass beakers. The beakers were placed in a drying oven at $60^{\circ} \mathrm{C}$ and dried to a constant weight. The water content of the detritus was calculated from the wet and dry weights. Weights of detritus used in the experiments are expressed as wet weights.

Measurement of TEP concentrations. Samples $(10 \mathrm{ml})$ for TEP concentrations and bacterial numbers were taken from each replicate and placed in sterile $30 \mathrm{ml}$ polystyrene universal bottles with $1 \%(\mathrm{v} / \mathrm{v})$ formalin as a preservative (Passow \& Alldredge 1994). These samples were stored in the dark at $4^{\circ} \mathrm{C}$ and subsequently, analysed for TEP concentration and bacterial numbers. TEP was measured using the method of Passow \& Alldredge (1995). A total of $6 \mathrm{ml}$ of each replicate was filtered at low vacuum $(<150 \mathrm{~mm} \mathrm{Hg})$ onto $0.4 \mu \mathrm{m}$ pore size polycarbonate filters (Cyclopore, Whatman). When the filter appeared dry, $1 \mathrm{ml}$ of Alcian blue solution $(0.02 \%$ Alcian blue in $0.06 \%$ acetic acid at $\mathrm{pH} 2.5$, filtered through a $0.2 \mu \mathrm{m}$ pore size filter) was drawn through the filter, followed by a rinse of $2 \mathrm{ml}$ distilled water. The filter was placed in a microcentrifuge tube and frozen until analysis. Alcian blue was extracted from the filters by soaking them in $4 \mathrm{ml}$ of $80 \% \mathrm{H}_{2} \mathrm{SO}_{4}$ for $2 \mathrm{~h}$, during which the samples were agitated several times. Absorbance was measured against a distilled water blank at $797 \mathrm{~nm}$ and calibrated using Gum Xanthan dissolved in artificial seawater salts (Harrison et al. 1980) over the range 0 to $30 \mu \mathrm{g} \mathrm{ml}^{-1}$. Results are expressed as Gum Xanthan equivalent (xanthan equiv.).

Measurement of carbohydrate concentrations. Samples for carbohydrate analysis $(1.3 \mathrm{ml})$ were placed in $1.5 \mathrm{ml}$ microcentrifuge tubes and frozen $\left(-20^{\circ} \mathrm{C}\right)$ until analysis. Two fractions of carbohydrate were measured; total carbohydrate concentration in the water above the detritus and the concentration of dissolved carbohydrates (defined as the carbohydrate in the filtrate passing through a $0.2 \mu \mathrm{M}$ filter [Cyclopore, Whatman]). Carbohydrate concentrations were measured using the phenol-sulphuric acid assay (Dubois et al. 1956). The samples were defrosted and $0.8 \mathrm{ml}$ was placed in a glass boiling tube and $0.4 \mathrm{ml}$ of phenol $(5 \%$ w/w) was added. After mixing, $2 \mathrm{ml}$ of concentrated $\mathrm{H}_{2} \mathrm{SO}_{4}$ was added rapidly using a bottle dispenser. Carbohydrate concentrations were linear over the range 0 to $50 \mathrm{\mu g} \mathrm{ml}^{-1}$ and were expressed as D-glucose equivalents (glucose equiv.), using a calibration curve made from D-glucose standards in artificial seawater salts.

Bacterial abundance. Bacteria were counted microscopically using epifluorescence after staining with the DNA specific stain DAPI (4'6-diamidino-2-phenylindole dihydrochloride) and filtration onto a $0.2 \mu \mathrm{m}$ filter 
according to Porter \& Feig (1980). These counts represented the concentration of free bacteria and bacteria visible on the surface of TEP and any other particles that were retained on the filter. On each slide, 400 bacteria were counted under epifluorescence using a Nikon Diaphot 200 inverted microscope with epifluorescence attachments. Blanks were prepared to give an estimate of background concentrations of bacteria, using artificial seawater which was $0.2 \mu \mathrm{m}$ filtered and autoclaved.

Experimental designs. Experiments were carried out with artificial seawater made according to Harrison et al. (1980), with the exception that trace metals and inorganic nutrients were not added. Media were double filtered though GF/C (Whatman) and $0.2 \mu \mathrm{m}$ filters (Cyclopore, Whatman) immediately before use. Unless stated otherwise, all experiments were carried out in $100 \mathrm{ml}$ glass flasks stopped with cotton wool and placed on an orbital shaker (100 rpm) in a dark constant temperature room at $13^{\circ} \mathrm{C}$. All glassware was acid-washed in $5 \% \mathrm{HCl}$ and rinsed 3 times with distilled water. Before sampling, the orbital shaker was switched off and flasks were allowed to settle for 30 min to ensure that the samples did not include macroalgal detritus particles. TEP did not sink out as it has approximately the same density as water, due to its highly hydrated state as a polymer gel (Passow 2002a). Statistical analysis was carried out with SPSS (version 11.0, SPSS).

Effect of macroalgal detritus concentration on TEP production. Macroalgal detritus was collected on 17 November 2002. Duplicate flasks were set up containing $0,0.1,0.5,1,2,3$ and $5 \mathrm{~g}$ of detritus in $50 \mathrm{ml}$ of artificial seawater. After $24 \mathrm{~h}$ on the shaker, samples were taken for carbohydrate and TEP concentrations.

TEP production over time. Two experiments were carried out to investigate TEP production on the timescale of days (long term) and another over a period of hours (short term). In the long-term experiment, approximately $5 \mathrm{~g}$ of macroalgal detritus (collected 21 October 2002) was placed in 6 replicate flasks with $75 \mathrm{ml}$ of filtered artificial seawater. Six control flasks were set up containing only filtered seawater. Samples for TEP and carbohydrate concentrations were taken after 24,72 and $144 \mathrm{~h}$.

In the short term experiment, $70 \mathrm{ml}$ of artificial seawater was placed into 3 flasks. Approximately $5 \mathrm{~g}$ of macroalgal detritus (collected 1 December 2002) was weighed into each flask and $10 \mathrm{ml}$ samples were taken at 0 (before addition of detritus), 15 and $240 \mathrm{~min}$ for TEP and carbohydrate concentrations. As this was a short-term experiment, the flasks were sampled immediately without a settling period; care was taken to ensure that small visible detritus particles were not included in the samples.
Effect of inorganic nutrients on TEP production. Approximately $5 \mathrm{~g}$ of detritus (collected 21 October 2002) was placed in 12 flasks to which $50 \mathrm{ml}$ of filtered artificial seawater was added. Dissolved inorganic nitrogen $\left(\mathrm{NaNO}_{3}\right)$ and phosphorus $\left(\mathrm{K}_{2} \mathrm{HPO}_{4}\right)$ were added to final concentrations of 300 and $100 \mu \mathrm{M}$, respectively to 6 of the flasks. Addition of inorganic nutrients at these concentrations did not produce Alcian blue stainable artefacts in the artificial seawater salts. The remaining 6 flasks served as controls. Water samples were taken after $48 \mathrm{~h}$ for carbohydrate, TEP and $\mathrm{pH}$.

Effect of temperature on TEP production. Approximately $5 \mathrm{~g}$ of detritus (collected 17 November 2002) was weighed into 12 flasks to which $50 \mathrm{ml}$ of filtered artificial seawater was added. Four replicate flasks were placed in the dark in constant temperature rooms at 4,13 and $26^{\circ} \mathrm{C}$. The flasks were regularly mixed by gentle swirling and sampled after $24 \mathrm{~h}$ for carbohydrate, TEP and bacterial numbers.

Effect of microbial activity on TEP production. Approximately $5 \mathrm{~g}$ of detritus (collected 4 November 2002) was weighed into 10 flasks containing $50 \mathrm{ml}$ of filtered artificial seawater. A further 5 flasks were set up containing only $50 \mathrm{ml}$ filtered artificial seawater. An antibiotic mixture $(0.5 \mathrm{ml})$ was added to 5 of the flasks containing detritus to a final concentration of $200 \mu \mathrm{g}$ $\mathrm{ml}^{-1}$ penicillin $\mathrm{G}$ and $100 \mu \mathrm{g} \mathrm{ml}^{-1}$ streptomycin sulphate. Distilled water $(0.5 \mathrm{ml})$ was added to the remaining flasks. All 15 flasks were placed on a shaker and sampled after $24 \mathrm{~h}$ for carbohydrate, TEP, bacterial numbers and $\mathrm{pH}$.

Abiotic formation of TEP from filtrates. Filtered artificial seawater $(100 \mathrm{ml})$ was placed in six $250 \mathrm{ml}$ flasks. Approximately $8 \mathrm{~g}$ of macroalgal detritus (collected 1 December 2002) was weighed into 3 of the flasks. The remaining 3 flasks served as controls. Flasks were sampled (19 ml removed) after $24 \mathrm{~h}$ for carbohydrate and TEP. After sampling, $50 \mathrm{ml}$ was taken from each flask and filtered through 2 sterile $0.2 \mu \mathrm{M}$ filters (Nalgene) mounted on a syringe in series. The filtrate was placed in an autoclaved $250 \mathrm{ml}$ flask. To inhibit bacterial growth, a mixed antibiotic solution $(0.5 \mathrm{ml})$ was added to each flask to a final concentration of $200 \mu \mathrm{g} \mathrm{ml}^{-1}$ penicillin $\mathrm{G}$ and $100 \mu \mathrm{g} \mathrm{ml}^{-1}$ streptomycin sulphate. The flasks were immediately sampled $(14 \mathrm{ml}$ removed) for carbohydrate and TEP. The remaining $36 \mathrm{ml}$ was returned to the shaker for a further $24 \mathrm{~h}$, after which it was sampled for carbohydrate and TEP.

Effect of media type on TEP production. Approximately $5 \mathrm{~g}$ of detritus (collected 17 November 2002) was placed in 10 flasks. Artificial seawater $(50 \mathrm{ml})$ was added to 5 of the flasks and natural seawater $(50 \mathrm{ml})$ was added to the remaining 5 flasks. After $24 \mathrm{~h}$, the flasks were sampled for carbohydrate and TEP. 

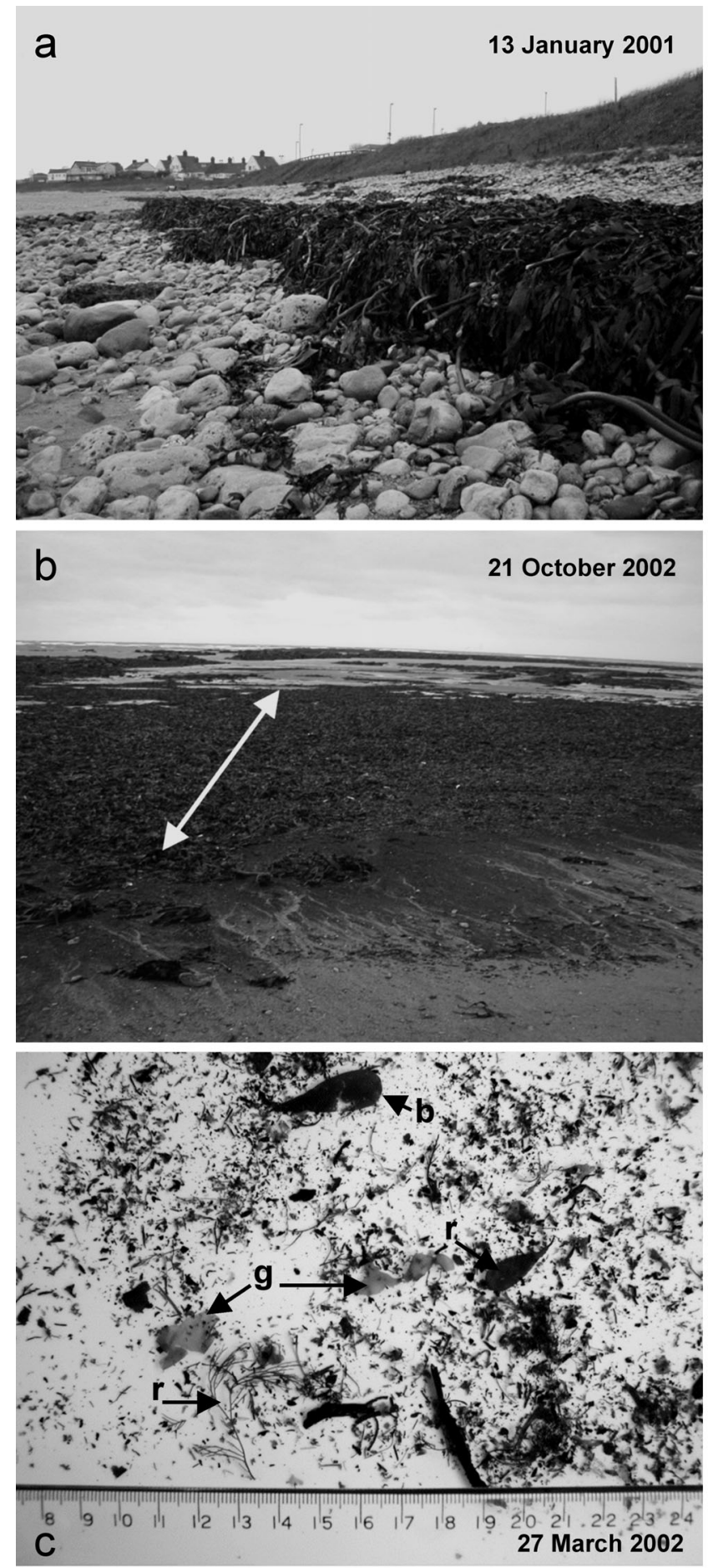

Fig. 1. Accumulations of macroalgal detritus on Whitburn beach on the North Sea coast of the UK. Dates indicate when each photo was taken. (a) Bank of kelp Laminaria digitata detached from the substrate and thrown up onto the strand line during a storm. (b) Accumulation of macroalgal detritus derived from a variety of taxa on a sandy part of the beach. The white arrow shows the width of the deposit. (c) Finely shredded detritus derived from a variety of red (r), green (g) and brown (b) macroalgae. Scale shows $\mathrm{cm}$

\section{RESULTS}

Accumulations of macroalgal detritus were observed on every trip to Whitburn Beach (Fig. 1). These deposits varied in location, extent and composition depending on recent weather conditions, tidal cycle and time of year. Macroalgal detritus was in the form of relatively intact plants that were dislodged during storms, such as the bank of Laminaria digitata in Fig. 1a. Alternatively, it was in the form of a mixture of relatively intact plants and shredded material (Fig. 1b). Even in accumulations of finely shredded material, it was still possible to recognise the deposits as macroalgal (Fig. 1c). The detritus had a high water content, varying between $76.8 \pm 0.4$ (mean $\pm \mathrm{SE}, \mathrm{n}=10)$ and $84.1 \pm 0.4($ mean $\pm \mathrm{SE}, \mathrm{n}=10) \%$ by mass on 21 October and 24 March 2002, respectively.

\section{Effect of macroalgal detritus concentration on TEP production}

After $24 \mathrm{~h}$, there were measurable concentrations of TEP associated with macroalgal detritus (Fig. 2a). Furthermore, increasing the concentration of macroalgal detritus in the flasks increased the TEP concentration measured after $24 \mathrm{~h}$. This relationship was linear (Fig. 2a) and significant ( $\mathrm{r}=0.97, \mathrm{p}<0.001, \mathrm{n}=14$ ):

$$
\text { TEP ( } \mu \text { g xanthan equiv. } \mathrm{ml}^{-1} \text { ) }=2.44 d+1.41
$$

where $d$ is macroalgal detritus concentration $\left(\mathrm{mg} \mathrm{ml}^{-1}\right)$. There was no significant relationship between dissolved carbohydrate and macroalgal detritus concentration (Fig. 2b). Similarly, there was no relationship between TEP and dissolved carbohydrate concentrations (data not shown). TEP normalised to the weight of macroalgal detritus was relatively constant, at approximately $120 \pm 20$ (mean \pm SE) $\mu g$ xanthan equiv. ( $g$ detritus) $^{-1}$. This value is corrected for the background TEP observed in the flasks containing no detritus.

\section{TEP production over time}

No TEP were measured in the control flasks which did not contain detritus in the long term experiment (data not shown). In flasks containing detritus, there was an increase in TEP over a timescale of days (Fig. 3a). The increase occurred between 24 and $72 \mathrm{~h}$ with no subsequent increase between 72 and $144 \mathrm{~h}$. No measurements were made at time zero; therefore, changes in TEP concentration between 0 and $24 \mathrm{~h}$ are unknown. However, the increase in TEP concentration over time to $123 \mu \mathrm{g}$ xanthan equiv. (g detritus) ${ }^{-1}$ was 


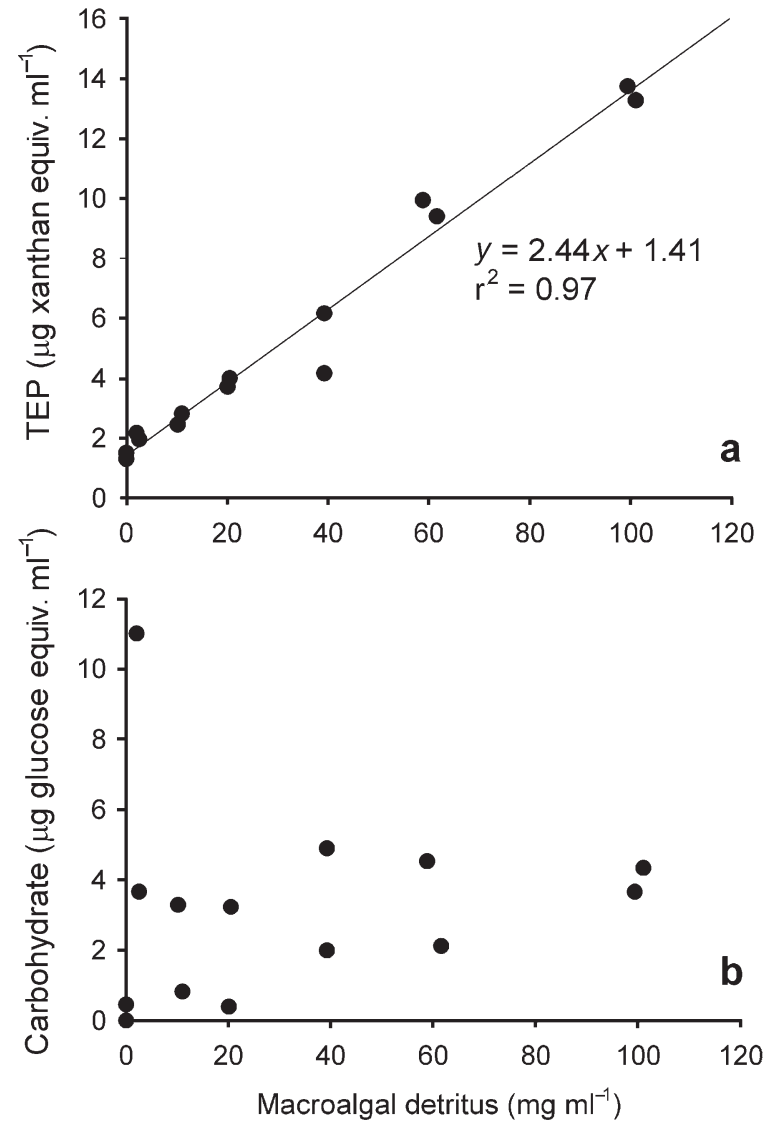

Fig. 2. Effect of macroalgal detritus concentration (weight) on (a) TEP concentration and (b) dissolved carbohydrate concentration. TEP and carbohydrate are expressed as Gum Xanthan and D-glucose equivalents, respectively

not significant (1-way ANOVA). In addition, the increase in dissolved carbohydrate concentration with time to $346 \mu \mathrm{g}$ glucose equiv. (g detritus) ${ }^{-1}$ (Fig. 3b) was not significant (1-way ANOVA). There was a significant decrease in $\mathrm{pH}(t=-41.471, \mathrm{p}<0.0001, \mathrm{n}=6)$ in the flasks containing detritus $(7.5 \pm 0.0[$ mean $\pm \mathrm{SE}])$ compared to the controls $(8.1 \pm 0.0[$ mean $\pm \mathrm{SE}])$. The starting $\mathrm{pH}$ of the media in both treatments was 8.1.

There was a significant increase in both carbohydrate $\left(F_{2,6}=19.0, \mathrm{p}<0.01\right)$ (Fig. $\left.4 \mathrm{a}\right)$ and $\operatorname{TEP}\left(F_{2,6}=\right.$ 8.78, p < 0.05) (Fig. 4b) with time in the short term experiment. However, the source of the variation was between TEP and carbohydrate concentrations at time 0 (before the addition of detritus), and the subsequent sampling points when the flasks contained detritus. There was no significant difference ( $t$-test) in mean dissolved carbohydrate concentration normalised to detritus weight at 15 and $240 \mathrm{~min}$; concentrations were approximately $102 \mu \mathrm{g}$ glucose equiv. (g detritus) $)^{-1}$. The mean $( \pm \mathrm{SE})$ TEP concentrations normalised to detritus weight at $15 \mathrm{~min}(39 \pm 6 \mu \mathrm{g}$ xanthan equiv. [g detritus $\left.]^{-1}\right)$ was less than half that at $240 \mathrm{~min}(90 \pm 26 \mu \mathrm{g}$ xanthan equiv. [g detritus] ${ }^{-1}$ ); however, there was no significant difference ( $t$-test) due to the large variation in TEP concentrations at $240 \mathrm{~min}$.

\section{Effect of inorganic nutrients on TEP production}

There was a significant difference between carbohydrate concentrations (Fig. 5a) in the control compared to the nutrient addition $\left(F_{1,20}=4.55, \mathrm{p}<0.05\right)$. There was no significant difference between the total and dissolved carbohydrate fractions (Fig. 5a), indicating that most of the carbohydrate in the media was able to pass through a $0.2 \mu \mathrm{m}$ filter. Mean dissolved carbohydrate concentrations were $254 \mu \mathrm{g}$ glucose equiv.

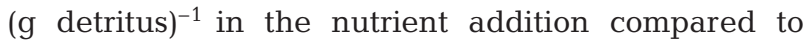
$203 \mu \mathrm{g}$ glucose equiv. (g detritus) ${ }^{-1}$ in the controls. Mean TEP concentrations in the nutrient addition treatment (Fig. 5b) were significantly $(t=2.671, \mathrm{p}<$ $0.05, \mathrm{n}=6)$ higher $\left(262 \mu \mathrm{g}\right.$ xanthan equiv. [g detritus] $\left.{ }^{-1}\right)$ in the nutrient additions compare to the control $(75 \mu \mathrm{g}$ xanthan equiv. [g detritus $]^{-1}$ ).

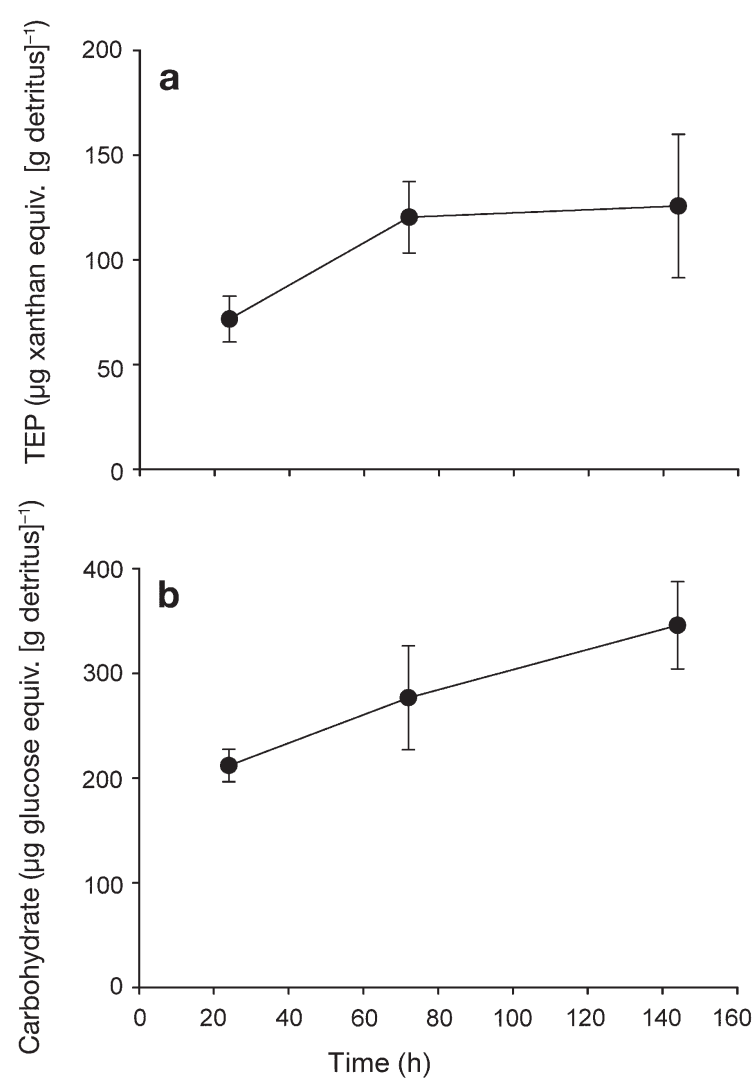

Fig. 3. (a) TEP concentration and (b) dissolved carbohydrate concentration associated with macroalgal detritus over $6 \mathrm{~d}$ (144 h). TEP and carbohydrate are expressed as Gum Xanthan and D-glucose equivalents, respectively, and normalised to detritus weight. Data points show mean \pm SE $(n=6)$ 

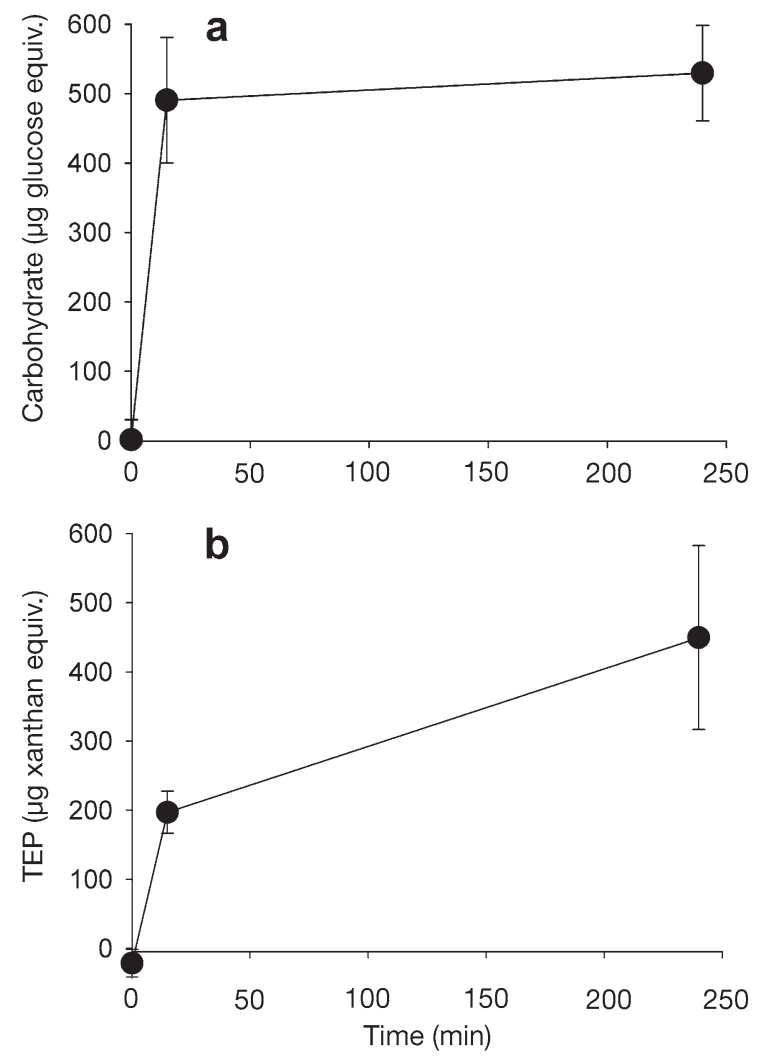

Fig. 4. (a) Total dissolved carbohydrate and (b) total TEP associated with macroalgal detritus over $240 \mathrm{~min}(4 \mathrm{~h})$. TEP and carbohydrate are expressed as Gum Xanthan and D-glucose equivalents, respectively. Data points show mean $\pm \mathrm{SE}(\mathrm{n}=3)$

\section{Effect of temperature on TEP production}

Temperature affected both carbohydrate and TEP concentrations (Fig. 6). There was a significant difference between total $\left(F_{2,9}=9.58, \mathrm{p}<0.01\right)$ and dissolved $\left(F_{2,9}=47.4, \mathrm{p}<0.001\right)$ carbohydrate concentrations at different temperatures; concentrations increased with increasing temperature (Fig. 6a). Mean TEP concentrations were 26 and $23 \mu \mathrm{g}$ xanthan equiv. (g detritus) ${ }^{-1}$ at 4 and $13^{\circ} \mathrm{C}$, respectively, compared to $86 \mu \mathrm{g}$ at $26^{\circ} \mathrm{C}$. (Fig. 6b). The difference in TEP concentration with temperature was significant $\left(F_{2,9}=9.49, \mathrm{p}<0.01\right)$. Although bacteria increased with increasing temperature (Fig. 6c), there was no significant difference between the bacterial numbers at the different temperatures.

\section{Effect of microbial activity on TEP production}

There were significantly different carbohydrate concentrations (both total $\left[F_{2,12}=15.8, \mathrm{p}<0.001\right]$ and dissolved $\left.\left[F_{2,12}=13.2, \mathrm{p}<0.001\right]\right)$ in the flasks, depending on the treatment (Fig. 7a). Negligible carbohydrate concentrations accumulated in the control flasks to which no detritus was added. In the flasks containing detritus, there was significantly more total carbohydrate $(\mathrm{p}<0.05)$ in the treatments with antibiotics $(65 \pm$ 14 compared to $29 \pm 3 \mu \mathrm{g}$ glucose equiv. $\mathrm{ml}^{-1}$ [mean \pm $\mathrm{SE}]$ ); although there was more dissolved carbohydrate in the flasks treated with antibiotics, the difference was not statistically significant (Fig. 7a).

TEP accumulated in the flasks which contained detritus (Fig. 7b), although low concentrations of TEP were also measured in the control flasks. TEP concentrations were significantly different $\left(F_{2,12}=9.86, \mathrm{p}<\right.$ 0.001 ) between treatments; the source of this variation was between the control and the treatments containing detritus. There was no difference in TEP concentrations between the treatments containing detritus $(13 \pm$ 1 with antibiotics compared to $15 \pm 4 \mu \mathrm{g}$ xanthan equiv. $\mathrm{ml}^{-1}$ [mean $\left.\pm \mathrm{SE}\right]$ without antibiotics).
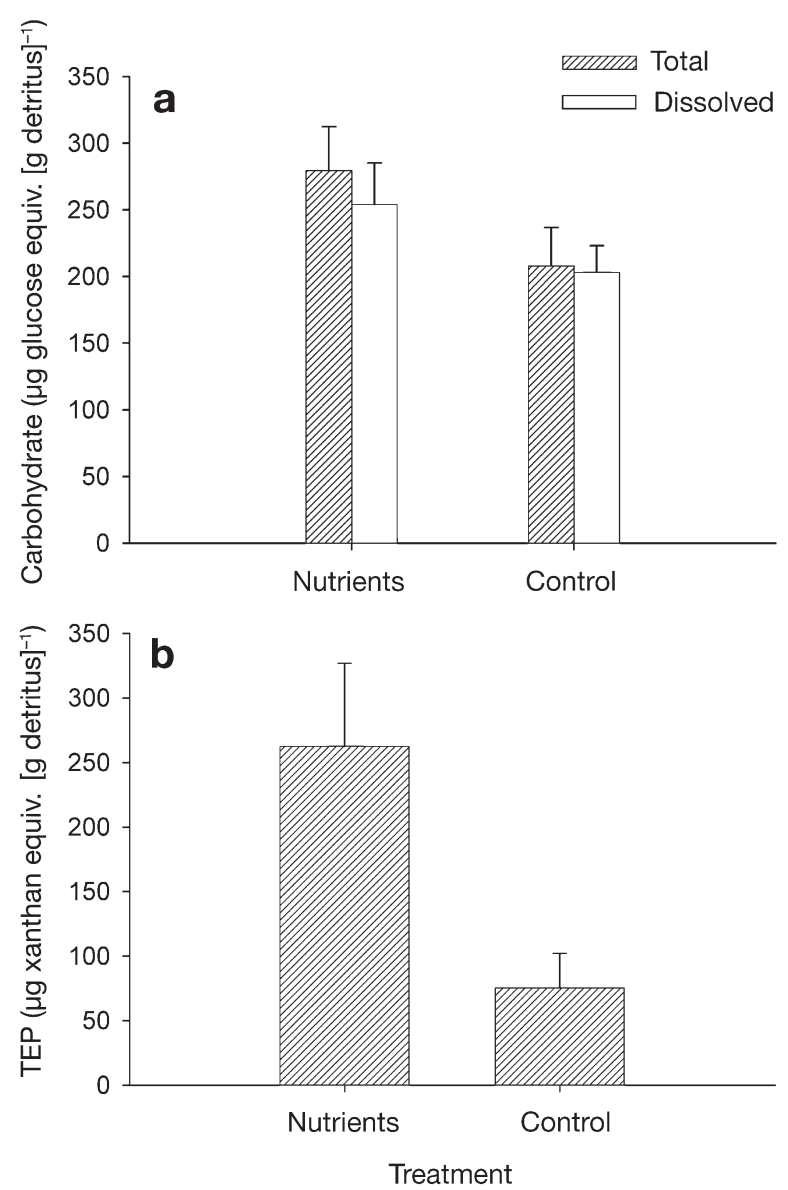

Fig. 5. Effect of inorganic nutrient addition to macroalgal detritus on (a) total and dissolved carbohydrate concentrations and (b) TEP concentration. TEP and carbohydrate are expressed as Gum Xanthan and D-glucose equivalents, respectively, and normalised to macroalgal detritus weight. Bars show mean + SE $(n=6)$ 
Antibiotics did not eliminate bacteria after $24 \mathrm{~h}$; there were $3.19 \times 10^{6} \pm 0.48 \times 10^{6}$ cells ml $^{-1}$ (mean $\pm \mathrm{SE}$ ) in the flasks containing detritus with antibiotics, compared to $7.81 \times 10^{6} \pm 1.50 \times 10^{6}$ cells $\mathrm{ml}^{-1}$ in the treatment containing detritus (Fig. $7 \mathrm{c}$ ). Bacterial numbers were lowest in the control, which contained $0.84 \times 10^{6}$ $\pm 0.11 \times 10^{6}$ cells ml ${ }^{-1}$ (mean $\pm \mathrm{SE}$ ). There was a significant difference $\left(F_{2,12}=15.1, \mathrm{p}<0.001\right)$ in bacterial numbers, with post hoc analysis (Tukey), indicating there were significantly $(p<0.05)$ more bacteria in the detritus treatment compared to both the treatment with antibiotics and the control. There was no significant difference in bacterial numbers between the control and antibiotic treatment. In the treatments containing detritus, there was a significant $\left(F_{2,12}=181, \mathrm{p}<\right.$ 0.001 ) reduction in $\mathrm{pH}$, indicating microbial respiration in those 2 treatments (Fig. 7d).

\section{Abiotic formation of TEP from filtrates}

TEP $\left(10 \pm 1 \mu g\right.$ xanthan equiv. $\mathrm{ml}^{-1}$ [mean $\left.\left.\pm \mathrm{SE}\right]\right)$ accumulated in flasks containing detritus after $24 \mathrm{~h}$ (Fig. 8). Filtration removed TEP and there was no subsequent abiotic formation of TEP in flasks after shaking for a further $24 \mathrm{~h}$ (Fig. 8). However, although TEP concentrations changed during the experiment, dissolved carbohydrates were not affected. After the first $24 \mathrm{~h}$ incubation, dissolved carbohydrates were $32 \pm$ $21 \mu \mathrm{g}$ glucose equiv. $\mathrm{ml}^{-1}$ and they were $39 \pm 25 \mu \mathrm{g}$ glucose equiv. $\mathrm{ml}^{-1}$ (mean $\pm \mathrm{SE}$ ) at the end of the experiment. The high standard error of the carbohydrate concentration was caused by consistently high dissolved carbohydrate concentrations in 1 of the 3 replicates. TEP and carbohydrate concentrations were negligible in the controls.

\section{Effect of media type on TEP production}

Whether the detritus was incubated in natural or artificial seawater affected TEP and carbohydrate accumulation in the flasks (Fig. 9). Significantly $(t=$ $2.98, \mathrm{n}=10, \mathrm{p}<0.05)$, more total carbohydrate accumulated in artificial (150 $\pm 6 \mu \mathrm{g}$ glucose equiv. [g detritus $\left.^{-1}\right)$ compared to natural seawater $(114 \pm 10 \mu \mathrm{g}$ glucose equiv. $\left.[g \text { detritus }]^{-1}\right)($ mean $\pm \mathrm{SE})$. There was no significant difference in dissolved carbohydrate concentrations between artificial $(87 \pm 11 \mu \mathrm{g}$ glucose equiv. [g detritus] $\left.{ }^{-1}\right)$ and natural $(99 \pm 9 \mu \mathrm{g}$ glucose equiv. [g detritus] ${ }^{-1}$ ) seawater. TEP concentration was significantly $(t=3.23, \mathrm{n}=10, \mathrm{p}<0.05)$ higher in artificial $\left(108 \pm 14 \mu \mathrm{g}\right.$ xanthan equiv. [g detritus] $\left.{ }^{-1}\right)$ compared to natural seawater $(60 \pm 5 \mu \mathrm{g}$ xanthan equiv. [g detritus $^{-1}$ ).
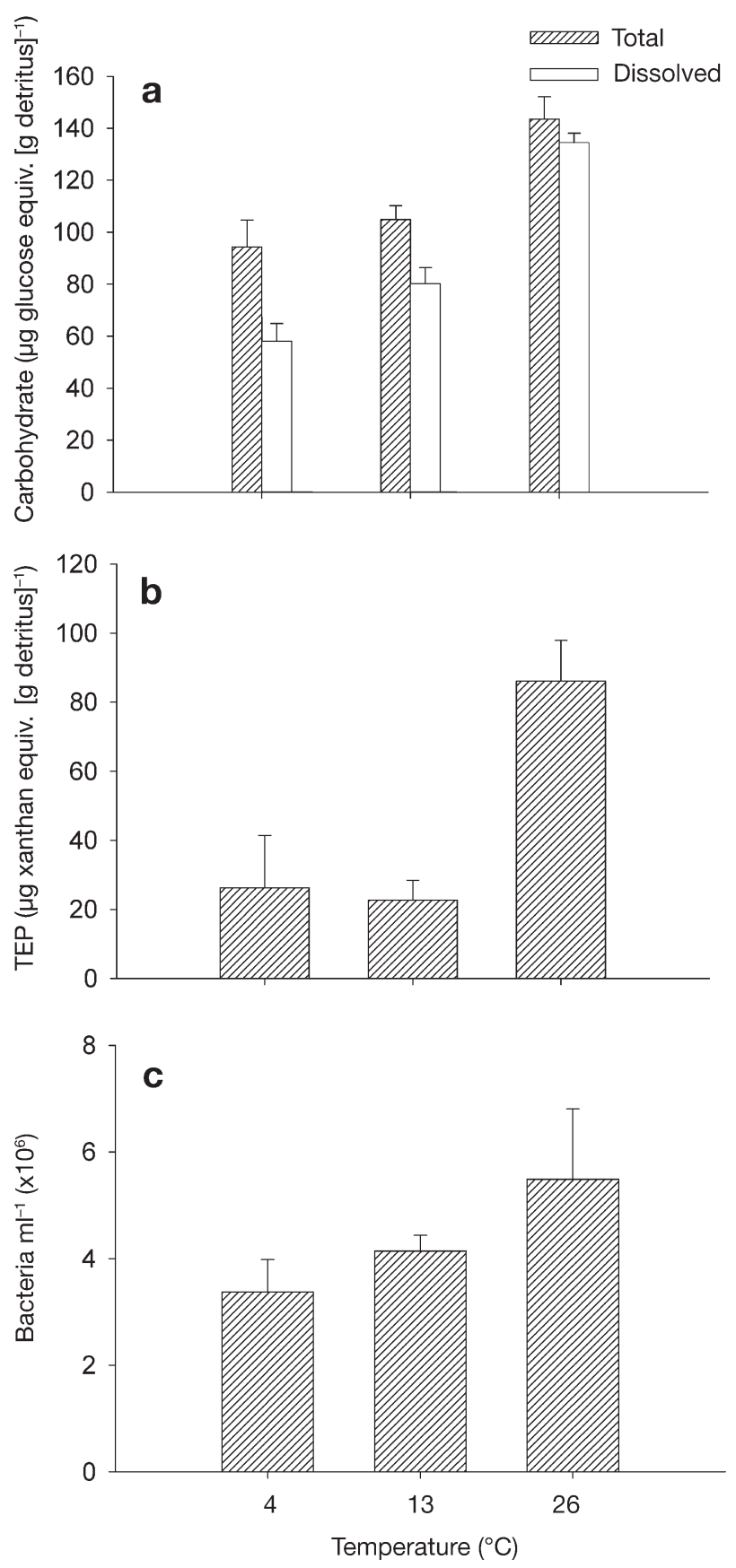

Fig. 6. Effect of temperature on (a) total and dissolved carbohydrate concentrations, (b) TEP concentration and. (c) bacteria associated with macroalgal detritus. TEP and carbohydrate are expressed as Gum Xanthan and D-glucose equivalents, respectively, and normalised to macroalgal detritus weight. Bars show mean $+\mathrm{SE}(\mathrm{n}=4)$

\section{DISCUSSION}

To the author's knowledge, these data represent the first to show that macroalgal detritus is a source of TEP. Alber \& Valiela (1994) produced organic aggregates by 

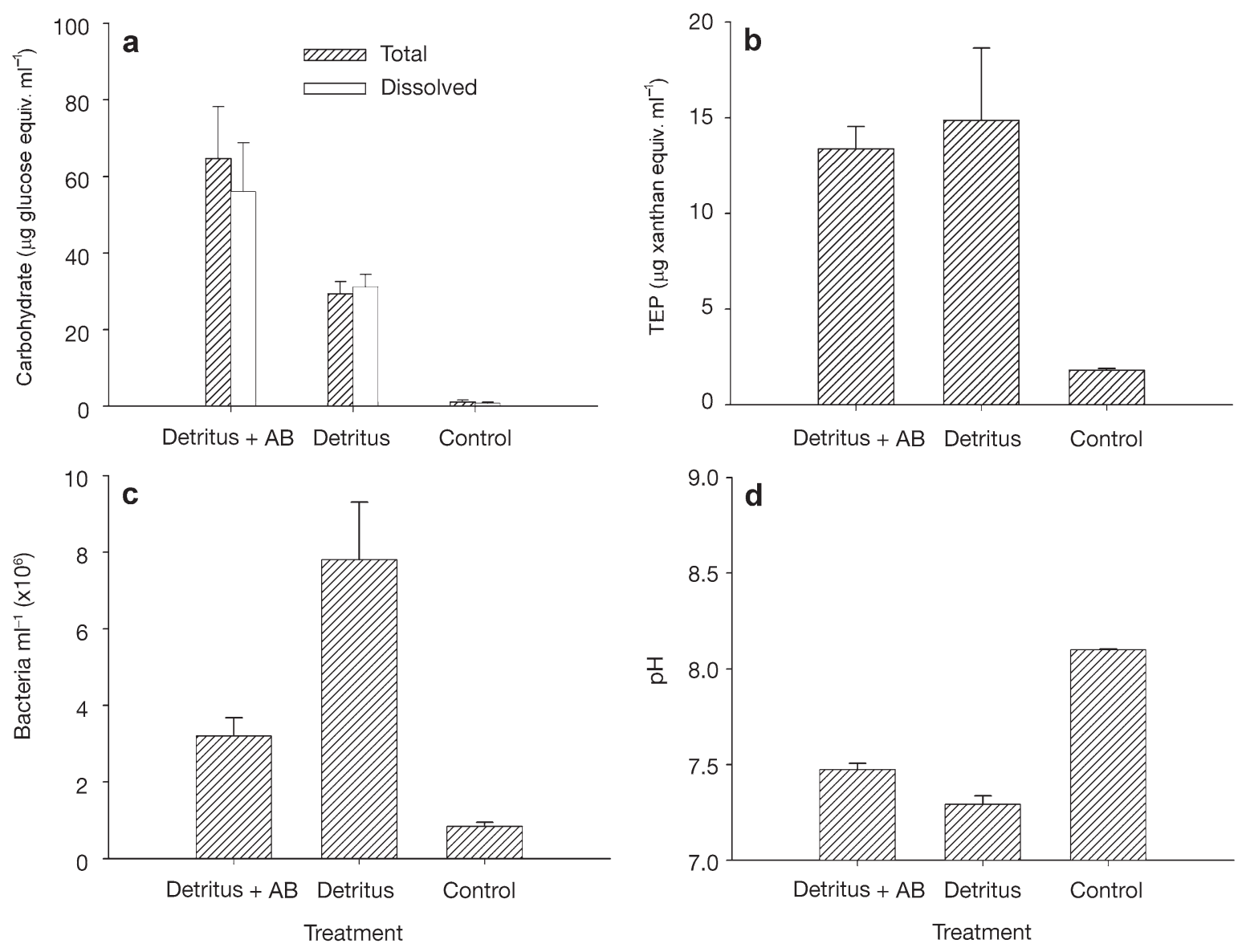

Fig. 7. Effect of antibiotics (AB) on (a) total and dissolved carbohydrate concentrations, (b) TEP concentration, (c) bacteria and (d) $\mathrm{pH}$ associated with macroalgal detritus. TEP and carbohydrate are expressed as Gum Xanthan and D-glucose equivalents, respectively. Bars show mean $+\mathrm{SE}(\mathrm{n}=5)$

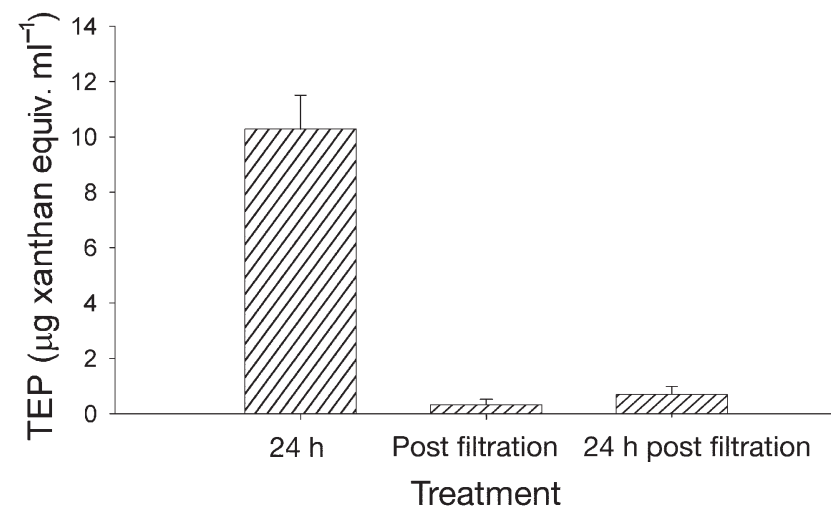

Fig. 8. Abiotic formation of TEP in filtered artificial seawater which had been incubated with macroalgal detritus. TEP are expressed as Gum Xanthan equivalent. Graph shows TEP concentrations at 3 stages in the experiment: TEP concentration after a $24 \mathrm{~h}$ incubation with macroalgal detritus, immediately after filtration and $24 \mathrm{~h}$ after filtration. Bars show mean +

$$
\mathrm{SE}(\mathrm{n}=3)
$$

bubbling dissolved organic carbon (DOC) leached from macroalgae. The aggregates contained large numbers of bacteria and stained with Alcian blue, suggesting that they contained TEP. However, the authors did not specifically assay for TEP nor discuss its presence. Ramaiah et al. (2001) showed that the macroalga Undaria pinnatifida produced TEP, but this work was carried out with intact plants rather than the fragmented algal material in various states of decay used in the present study.

TEP are particles that stain with Alcian blue and, therefore, consist largely of acid polysaccharides (Alldredge et al. 1993, Passow 2002a). Living macroalgae contain acid polysaccharides in their cell walls (Chiovitti et al. 2001, Rúperez et al. 2002). Therefore, a major structural component of many macroalgae is formed from the same group of polysaccharides as TEP. Moreover, polysaccharide mucilages are known to be released by intact macroalgae (Kroes 1970) and during the fragmentation and decay of kelp (Linley et al. 1981). Valiela et al. (1985) found that macroalgae 
lost 30 to $85 \%$ of their initial weight as dissolved organic matter (DOM) during the first 2 wk of decomposition. Consequently, it is not surprising that TEP is formed during the decay of macroalgal detritus.

Three mechanisms probably contributed to the formation of the polysaccharides that subsequently formed TEP: the release of intracellular polymers as a result of physical and enzymatic fragmentation of the detritus, release of exopolymers by microorganisms associated with the detritus, and polymer exudation by living fragments of macroalgae. It would be interesting to determine which of these sources contributed most to TEP production, though it is likely to vary with detrital source and age, factors which are difficult to determine from material collected off the beach. Measuring photosynthetic activity could be used to determine whether the detritus contained living macroalgal tissue. The photosynthetic activity of bulk material could be measured by oxygen production and consumption in the light and dark using Clark type oxygen electrodes, while chlorophyll fluorescence techniques could be used to assess the photosynthetic activity of individual detrital fragments.

This work was conducted over a period of months using macroalgal detritus collected at different times of the year. The chemical composition of the detritus probably varied depending on seasonal species composition and physiological status of the original macroalgae. Other factors introducing variability would have been age of the detritus, residence time on the shore and composition of the microbial community. It is very likely that there were significant differences in the chemical composition and TEP forming potential of detritus collected on different days. It would be interesting to investigate how detritus composition and quality affects TEP formation. Moreover, the detritus was stored at $5^{\circ} \mathrm{C}$ for varying lengths of time before each experiment; this may have affected the chemical composition of the detritus, composition of the microbial community, the relative contribution of different processes to TEP formation and the absolute amount of TEP produced during the experiments. Storage at $5^{\circ} \mathrm{C}$ was chosen as this was cold enough to reduce microbial activity, but not cold enough to freeze the detritus, which would have caused damage to intact macroalgal cells and enhanced leaching of DOC.

TEP concentration was found to be proportional to the amount of macroalgal detritus placed in a flask (Eq. 1). The intercept of this relationship was 1.41; therefore, there was a low background concentration $\left(1.41 \mu \mathrm{g}\right.$ xanthan equiv. $\mathrm{ml}^{-1}$ ) of TEP in the flasks that did not contain detritus (Eq. 1). Although Eq. (1) indicated that macroalgal detritus was a source of TEP, it did not indicate when the TEP was produced. Samples

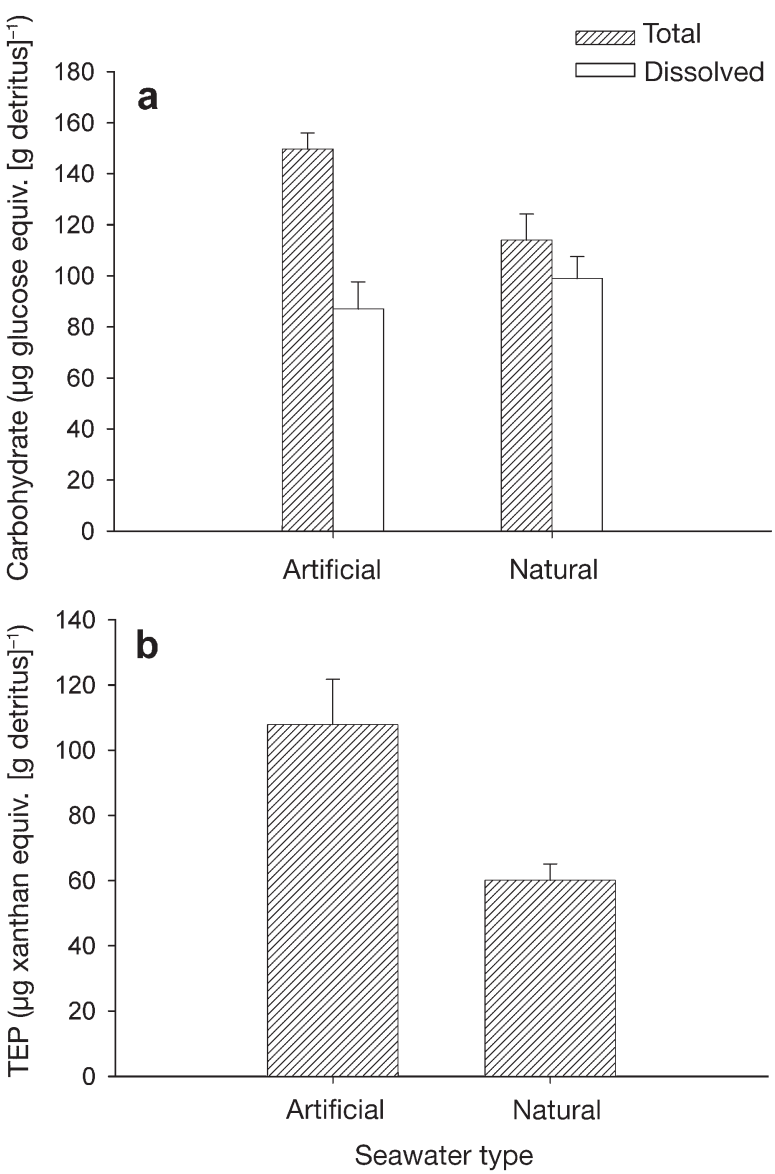

Fig. 9. Effect of media type on (a) total and dissolved carbohydrate concentrations and (b) TEP concentration associated with macroalgal detritus. TEP and carbohydrate are expressed as Gum Xanthan and D-glucose equivalents, respectively, and normalised to macroalgal detritus weight. Bars show mean + SE $(n=5)$

taken over time showed no significant change in TEP concentration over timescales of days or minutes. The majority of the TEP measured during the experiments was probably produced before the experiment started and was washed off the macroalgal detritus on immersion in artificial seawater. However, both nutrient additions and high temperature effected higher concentrations of TEP compared to the controls; indicating that there were processes significantly affecting TEP production on timescales of the duration of the experiments. TEP concentration at any point in time will be a net product of microbial and abiotic processes involved in their degradation as well as formation. Lower $\mathrm{pH}$ observed in flasks that contained detritus was probably due to elevated rates of microbial respiration compared to the control flasks. $\mathrm{CO}_{2}$ produced during respiration results in a drop in the $\mathrm{pH}$ of seawater (Dring 1982). 
There was generally no correlation between TEP and carbohydrate concentration. The dissolved carbohydrate pool probably included the polysaccharides and colloids that are precursors to TEP as well as carbohydrates of a lower molecular weight. The total carbohydrate pool would have included TEP, TEP precursors, other dissolved carbohydrates and non-TEP carbohydrate particles. It is difficult to assess what proportion of the carbohydrate pool was formed from TEP, as the measurements of both TEP and carbohydrate were relative; therefore, it is not possible to make direct comparison between the two. In both colorimetric assays, the amount of colour produced per unit of carbon will depend on the chemical composition as well as concentration of the carbohydrate being measured. Engel \& Passow (2001) related the Alcian blue adsorption of TEP to its carbon content and found that TEP carbon $\left(\mu \mathrm{g}^{-1}\right)$ could be obtained by multiplying TEP concentration ( $\mu \mathrm{g}$ xanthan equiv. $\mathrm{l}^{-1}$ ) by a factor of 0.75. Applying this relationship to the mean TEP concentrations in the nutrient addition experiment, there was approximately $197 \mu \mathrm{g}$ (g wet detritus) $)^{-1}$ with inorganic nutrient additions compared to $56 \mu \mathrm{g} \mathrm{C}$ ( $\mathrm{g}$ wet detritus) $^{-1}$ in the controls. However, this conversion was based on data derived from diatom cultures and natural assemblages dominated by diatoms. Engel \& Passow (2001) found species-specific relationships between carbon and TEP in diatoms. The relationship between carbon and Alcian Blue adsorption may be significantly different for TEP derived from macroalgal detritus. Furthermore, the amount of TEP produced and the relationship between carbon and TEP concentrations may change depending on the source of the macroalgal detritus, its age and the microorganisms associated with it. However, to understand the flux of carbon through coastal waters, it is important to determine how much organic carbon is in the form of TEP and its subsequent fate.

The flasks were allowed to settle for $30 \mathrm{~min}$ (except in the short term production experiment) before samples for TEP and carbohydrates were taken. This was to ensure that the samples were not contaminated with large detrital particles. However, there were probably some small particles other than TEP in suspension when the samples were taken. When natural water samples are filtered using the method of Passow \& Alldredge (1995), TEP and a variety of other particles will be retained on the filters. Generally, other types of particles do not interfere with the TEP assay (Passow 2002a), unless they are present in extremely high concentrations such as in sediment trap samples (Passow et al. 2001).

Although antibiotics reduced bacterial numbers significantly, there were still high numbers of bacteria and a significant $\mathrm{pH}$ decrease indicated respiration. Carbohydrate concentrations were higher in flasks treated with antibiotics, indicating that bacterial utilisation of the carbohydrate pool was partially inhibited; however, this did not affect the concentrations of TEP. Both carbohydrate and TEP concentrations increased with temperature, which may have been caused by increased microbial activity (respiration and growth) at higher temperatures. More than 3 times the TEP accumulated in flasks at $26^{\circ} \mathrm{C}$ compared to 4 and $13^{\circ} \mathrm{C}$. Temperatures of $26^{\circ} \mathrm{C}$ and higher occur on emersed UK beaches (though not in the water column) during the summer. Therefore, relatively high concentrations of TEP may form in summer accumulations of macroalgal detritus during low tide periods, to be subsequently released into the water column during tidal immersion. The addition of nutrients affected higher carbohydrate and TEP concentrations; TEP concentrations were more than 3 times those in the controls. This may have been due to a stimulation of microbial growth due to an alleviation of nutrient limitation. Microbial growth may affect higher TEP concentrations as a result of polymers exuded by microorganisms or exoenzymatic degradation of the detritus.

TEP did not form in shaken flasks containing dissolved carbohydrates derived from macroalgal detritus once the detritus and biological activity had been removed by filtration and the addition of antibiotics. Current models of TEP formation state that TEP is usually formed abiotically from biotic precursors of phytoor bacterioplankton origin (Passow 2002b). Bubble dissolution has long been known to produce organic particles in seawater (Johnson 1976, Johnson \& Cooke 1980); TEP have been produced in the laboratory by bubbling filtered seawater (Zhou \& Mopper 1998) and filtrates of diatom cultures (Mari 1999, Mari \& Dam 2004). Fluid shear has been used to generate TEP from filtered seawater derived from blooms dominated by diatoms or Phaeocystis spp. (Passow 2000) and the filtrates of diatom cultures (Engel \& Passow 2001). Therefore, it is surprising that TEP did not form in the filtrates derived from macroalgal detritus. It may have been that the mixing regime within the flasks was not conducive to the formation of TEP; however, Chin et al. (1998) found the spontaneous assembly of polymer gels in filtered seawater that was not mixed. It is also unlikely that the flasks were not left for long enough; Passow (2000) measured TEP after 24 h, whereas measurable TEP concentrations have been generated from the filtrates of diatom cultures in hours (Mari 1999) or even minutes (Mari \& Dam 2004). It may be that continued microbial activity was required to produce TEP from the carbohydrates released from macroalgal detritus or that TEP is produced directly from the fragmentation of detritus and not from the dissolved carbohydrate pool. It is unlikely that the antibiotics inhibited the abiotic formation of TEP or caused its breakdown 
as measurable TEP concentrations were observed in flasks containing antibiotics and detritus (Fig. 7)

Media composition affected TEP formation as there was almost twice as much TEP formed from detritus incubated in artificial seawater compared to detritus incubated in natural seawater. This may have been due to the different media selecting for different organisms with different production rates of TEP or its precursors. However, it is more likely that the chemical properties of the different media affected TEP concentration. Divalent cation concentration $\left(\mathrm{Ca}^{2+}\right.$ and $\left.\mathrm{Mg}^{2+}\right)$ is particularly important in the formation of TEP; therefore, differences in salinity or the relative salt composition of different media will affect TEP concentration. Divalent cations act as ionic bridges between polysaccharides in gels (Decho 1990). Removal of divalent cations by chelation with EDTA disrupts diatom aggregates glued together by acidic polysaccharides (Alldredge et al. 1993, Thornton \& Thake 1998). Higher concentrations of TEP in artificial seawater may have been due to relatively high concentrations of divalent cations compared to natural seawater. Unfortunately, the cation concentration of the natural seawater was not measured; therefore, comparisons of cation concentration cannot be made.

These experiments show that macroalgal detritus is a source of TEP. Given that large accumulations of detritus occur on temperate shores (Fig. 1), there may be significant export of TEP into coastal waters, with numerous effects on particle dynamics, carbon biogeochemistry and food web dynamics. TEP stickiness means that they affect the aggregation of other particles in the water column, including bacteria, phytoplankton and sediment (Passow et al. 1994, 2000, Engel 2000, Passow 2002a). This can result in an enhanced downward flux of these materials towards the seabed (Passow et al. 2001, Passow 2002a). Consequently, a significant export of TEP from the littoral may affect sedimentation and carbon burial offshore. TEP production can impact the feeding of organisms that filter or selectively pick particles out of the water column. Modeling has suggested that non-living, submicrometer particles may be an important food source for both protists and benthic suspension feeders (Shimenta 1993). Protists have been shown to feed on and assimilate colloid forming polysaccharides (Sherr 1988, Tranvik et al. 1993). Malej \& Harris (1993) found that copepod feeding was inhibited by exopolymers, whereas Prieto et al. (2001) found that copepods did not actively feed on TEP. However, the euphausiid Euphausia pacifica can use TEP as a food source (Passow \& Alldredge 1999) and bacterial exopolymer coated beads were utilised by the harpacticoid copepod Laophonte sp. (Decho \& Moriarty 1990). Passow \& Alldredge (1999) found that E. pacifica was feeding on aggregates composed of TEP and nano-sized particles, leading them to conclude that TEP may enable macrozooplankton to feed directly on nano- and picoplankton, thus bypassing the microbial loop. Although the nutritional quality of TEP may be low due to its high C:N ratio (Engel \& Passow 2001, Mari et al. 2001), the incorporation of small particles into the TEP matrix may produce aggregates with the same $\mathrm{C}: \mathrm{N}$ ratio as diatoms (Passow \& Alldredge 1999). Therefore, export of TEP from the littoral may have a significant effect on food web dynamics in the coastal sea.

Acknowledgements. This research was supported by the University of Sunderland, UK.

\section{LITERATURE CITED}

Alber M, Valiela I (1994) Production of organic aggregates from macrophyte-derived dissolved organic material. Limnol Oceanogr 39:37-50

Alldredge AL, Passow U, Logan BE (1993) The abundance and significance of a class of large, transparent organic particles in the ocean. Deep-Sea Res I 40:1131-1140

Azam F, Long RA (2001) Sea snow microcosms. Nature 414: 495-497

Chin WC, Orellana MV, Verdugo P (1998) Spontaneous assembly of marine dissolved organic matter into polymer gels. Nature 391:568-571

Chiovitti A, Kraft GT, Bacic A, Liao ML (2001) Gelling polysaccharides from Australian seaweeds: research and potential. Mar Freshw Res 52:917-935

Corzo A, Morillo JA, Rodríguez S (2000) Production of transparent exopolymer particles (TEP) in cultures of Chaetoceros calcitrans under nitrogen limitation. Aquat Microb Ecol 23:63-72

Crocker KM, Passow U (1995) Differential aggregation of diatoms. Mar Ecol Prog Ser 117:249-257

Decho AW (1990) Microbial exopolymer secretions in ocean environments: their role(s) in food webs and marine processes. Oceanogr Mar Biol Annu Rev 28:78-153

Decho AW, Moriarty DJW (1990) Bacterial exopolymer utilization by a harpacticoid copepod: a methodology and results. Limnol Oceanogr 35:1039-1049

Dring MJ (1982) The biology of marine plants. Edward Arnold, London

Dubois M, Gilles KA, Hamilton JK, Rebers PA, Smith F (1956) Colorimetric method for determination of sugars and related substances. Anal Chem 28:350-356

Engel A (2000) The role of transparent exopolymer particles (TEP) in the increase in apparent stickiness $(\alpha)$ during the decline of a diatom bloom. J Plankton Res 22:485-497

Engel A, Passow U (2001) Carbon and nitrogen content of transparent exopolymer particles (TEP) in relation to their Alcian Blue adsorption. Mar Ecol Prog Ser 219:1-10

Harrison PJ, Waters RE, Taylor FJR (1980) A broad spectrum artificial seawater medium for coastal and open ocean phytoplankton. J Phycol 16:28-35

Johnson BD (1976) Nonliving organic particle formation from bubble dissolution. Limnol Oceanogr 21:444-446

Johnson BD, Cooke RC (1980) Organic particle and aggregate formation resulting from the dissolution of bubbles in seawater. Limnol Oceanogr 25:653-661 
Kroes HM (1970) Excretion of mucilage and yellow-brown substances by some brown algae from the intertidal zone. Bot Mar 8:107-110

Linley EAS, Newell RC, Bosma SA (1981) Heterotrophic utilisation of mucilage released during fragmentation of kelp (Ecklonia maxima and Laminaria pallida). I. Development of microbial communities associated with the degradation of kelp mucilage. Mar Ecol Prog Ser 4:31-41

Malej A, Harris RP (1993) Inhibition of copepod grazing by diatom exudates: a factor in the development of mucus aggregates. Mar Ecol Prog Ser 96:33-42

Mari X (1999) Carbon content and C:N ratio of transparent exopolymeric particles (TEP) produced by bubbling exudates of diatoms. Mar Ecol Prog Ser 183:59-71

Mari X, Dam HG (2004) Production, concentration, and isolation of transparent exopolymer particles using paramagnetic functionalized microspheres. Limnol Oceanogr: Methods 2:13-24

Mari X, Kiørboe T (1996) Abundance, size distribution and bacterial colonization of transparent exopolymeric particles (TEP) during spring in the Kattegat. J Plankton Res 18:969-986

Mari X, Beauvais S, Lemée R, Pedrotti ML (2001) Non-Redfield C:N ratio of transparent exopolymeric particles in the northwestern Mediterranean Sea. Limnol Oceanogr 46: $1831-1836$

Passow U (2000) Formation of transparent exopolymer particles, TEP, from dissolved precursor material. Mar Ecol Prog Ser 192:1-11

Passow U (2002a) Transparent exopolymer particles (TEP) in aquatic environments. Prog Oceanogr 55:287-333

Passow U (2002b) Production of transparent exopolymer particles (TEP) by phyto and bacterioplankton. Mar Ecol Prog Ser 236:1-12

Passow U, Alldredge AL (1994) Distribution, size and bacterial colonization of transparent exopolymer particles (TEP) in the ocean. Mar Ecol Prog Ser 113:185-198

Passow U, Alldredge AL (1995) A dye-binding assay for the spectrophotometric measurement of transparent exopolymer particles (TEP). Limnol Oceanogr 40:1326-1335

Passow U, Alldredge AL (1999) Do transparent exopolymer particles (TEP) inhibit grazing by the euphausiid Euphausia pacifica? J Plankton Res 21:2203-2217

Passow U, Alldredge AL, Logan BE (1994) The role of particulate carbohydrate exudates in the flocculation of diatom blooms. Deep-Sea Res I 41:335-357

Passow U, Shipe RF, Murray A, Pak DK, Brzezinski MA, All-

Editorial responsibility: Otto Kinne (Editor),

Oldendorf/Luhe, Germany dredge AL (2001) The origin of transparent exopolymer particles (TEP) and their role in the sedimentation of particulate matter. Cont Shelf Res 21:327-346

Porter KG, Feig YS (1980) The use of DAPI for identifying and counting aquatic microflora. Limnol Oceanogr 25:943-948

Prieto L, Sommer F, Stibor H, Koeve W (2001) Effects of planktonic copepods on transparent exopolymeric particles (TEP) abundance and size spectra. J Plankton Res 23: 515-525

Ramaiah N, Yoshikawa T, Furuya K (2001) Temporal variations in transparent exopolymer particles (TEP) associated with a spring diatom bloom in a subarctic ria in Japan. Mar Ecol Prog Ser 212:79-88

Rupérez P, Ahrazem O, Leal JA (2002) Potential antioxidant capacity of sulfated polysaccharides from the edible marine brown seaweed Fucus vesiculosus. J Agric Food Chem 50:840-845

Sherr EB (1988) Direct use of high molecular weight polysaccharide by heterotrophic flagellates. Nature 335:348-351

Shimenta J (1993) Diffusional encounter of submicrometer particles and small cells by suspension feeders. Limnol Oceanogr 38:456-465

Simon M, Grossart HP, Schweitzer B (2002) Microbial ecology of organic aggregates in aquatic ecosystems. Aquat Microb Ecol 28:175-211

Stoderegger KE, Herndl GJ (1999) Production of exopolymer particles by marine bacterioplankton under contrasting turbulence conditions. Mar Ecol Prog Ser 189:9-16

Thornton DCO (2002) Diatom aggregation in the sea: mechanisms and ecological implications. Eur J Phycol 37: 149-161

Thornton DCO, Thake B (1998) Effect of temperature on the aggregation of Skeletonema costatum (Bacillariophyceae) and the implication for carbon flux in coastal waters. Mar Ecol Prog Ser 174:223-231

Tranvik LJ, Sherr EB, Sherr BF (1993) Uptake of colloidal DOM by heterotrophic flagellates in seawater. Mar Ecol Prog Ser 92:301-309

Valiela I, Teal JM, Allen SD, Vanetten R, Goehringer D, Volkmann S (1985) Decomposition in salt-marsh ecosystems the phases and major factors affecting disappearance of above-ground organic-matter. J Exp Mar Biol Ecol 89: $29-54$

Zhou J, Mopper K (1998) The role of surface-active carbohydrates in the formation of transparent exopolymer particles by bubble adsorption of seawater. Limnol Oceanogr 43:1860-1871

Submitted: January 29, 2004; Accepted: July 15, 2004

Proofs received from author(s): October 22, 2004 